\title{
Kenneth Chan
}

\section{Writers As Teachers, Teachers As Writers: Creative Writing Programs in the US}

\begin{abstract}
This paper looks at issues emanating from creative writing programs focussing, in particular, on the literary scene in North America. With the proliferation of creative writing schools in the USA in the second half of the twentieth century it has become possible for talented writers - be they poets, novelists or dramatists - to begin their apprenticeship as undergraduates and progress through higher degrees to become teachers, to continue their writing yet never leave the campus. It was not always thus; and while it is a phenomenon that many writers have welcomed, it is also something that has attracted its share of critics.
\end{abstract}

Alfred Kazin has said that there was once a time in America when all its writers seemed to be clergymen. By the end of the nineteenth century writers tended to start in journalism, a tradition that persisted into the 1920s. Kazin mentions such practising journalists as Mark Twain, Dreiser, Crane, and Hemingway (Kazin 242).

After World War II, however, a great many writers were located in the universities, a trend that embraced poets, novelists, and dramatists. Poets, especially, had been wrapped in the "academic cocoon". (Kazin 242-3). There was Theodore Roethke, Randall Jarrell, Richard Wilbur and Robert Lowell. It was rare, Kazin pointed out, to find someone like Elizabeth Bishop, who did not teach at all. (243). (He must have written his piece before Bishop went into teaching because she was a teacher at Harvard, New York University, and MIT) (Spires 123).

The teaching I am referring to is in creative writing. Of this calling the novelist Bernard Malamud comments:

I have done it because I teach decently well but I wouldn't recommend that anyone devote his life to teaching writing if he takes little pleasure in informing others. Elsewhere I've said about teaching creative writing that one ought to keep in mind he is not so much teaching the art of imaginative writing as he is encouraging people with talent how to work as writers. Writing courses are of limited value, although in certain cases they may encourage young writers to read good fiction with the care it deserves. However, I think about a year of these courses should be enough for any serious student. Thereafter writing must become a way of life. (Malamud 9)

In an interview with the Paris Review he once said: 
you teach writers - assuming a talent. At the beginning young writers pour it out without much knowing the nature of their talent. What you try to do is hold a mirror up to their fiction so, in a sense, they can see what they're showing. (Stern 155)

Malamud was guardedly in favour of creative writing programs. More enthusiastic was the novelist and poet, William Goyen, who said that teaching writing was draining, especially the way he did it, because he believed that "everybody can write. And in believing and teaching this, what happens, of course, is enormous productivity on the part of many students" (Phillips 189). John Gardner, himself a distinguished novelist and literary critic, comments wryly that:

When I first began teaching my main job was in creative writing, and I discovered very quickly that it's fairly easy to transform an eager, intelligent student to a publishing creative writer. Silly as it sounds, that discovery was a shock to my ego and changed my whole approach to writing fiction... Since I found out that anyone has stories he can tell, and once you've shown him a little technique, can tell them relatively well, I was determined to set myself apart from the herd...Also, I quit teaching creative writing, maybe partly from annoyance that my students were as good as I was, but mainly in hopes of learning the things I had to know to become a good writer. (Ferguson et al 399)

\section{In The Beginning}

One of the most famous creative writing schools in America is the Iowa Writers' Workshop which began in 1939. But the University of Iowa actually offered creative writing courses as far back as 1897 and, in 1922, it became one of the first tertiary institutions in America to permit students to submit original works of art, literature, and music in place of a traditional masters thesis. In 1931 it expanded its scope and decided to allow the grant of a PhD for creative works. Although no creative masters in English was submitted until 1931, five such were awarded the following year. Among the recipients was Wallace Stegner, later a Pulitzer Prize-winning novelist and founder of the writing program at Stanford University, and Paul Engle, whose thesis won him the 1932 Yale Series of Younger Poets Award. Engle went on to head the Iowa Writers' Workshop and he is credited with putting it on the literary map by drawing students and faculty from all over the country (Rood 108-9).

The list of those who held permanent and visiting fellowships at Iowa includes R.V. Cassill, Robert Lowell, Donald Justice, Hortense Calisher, Philip Roth, Richard Yates, Kurt Vonnegut, Robert Coover, Gail Godwin, John Irving, Raymond Carver, John Cheever, Stanley Elkin, Frank Conroy and Vance Bourjaily. Many in this list were themselves former workshop students (Rood 109).

Mention should also be made of the Stanford Writing Program. Stegner comments that he mapped out a program in 1947 after he realised that, in the immediate post-war years, there were students returning from the forces who were of "unprecedented maturity, experience, and seriousness" and for whom the university needed to provide something more substantial than the routine writing course offered to 18-year-old freshmen (Rood 98).

The Stegner program was designed to avoid any accusation that a writing degree was a soft option. The requirements for an MA in creative writing was identical to an MA in English with the student having the added load of completing "an acceptable thesis of stories, poems, or a novel" (Rood 98). All writing courses were to be taught by writers, including visiting writers who might lecture or teach for a term or a year. One-year 
fellowships, six in all, were proposed in fiction, poetry, and drama. Provision was made for publication of volumes of writing and prizes were set up of $\$ 1000$ each for the best story, novel, drama, and group of poems (98).

Through experience it was decided, after several years, to drop the prizes because, while they generated intense competition they also engendered bad feeling. Drama fellowships were eliminated because it was felt that drama writing more properly fitted with the Speech and Drama Department. Fellows, says Stegner, did not have to be matriculated students or candidates for degrees. Their task was to write as well as they knew how and to participate in the advanced seminars in poetry or fiction (Rood 99).

The list of visiting writers has included Katharine Anne Porter, Frank O'Connor, Malcolm Cowley, Elizabeth Bowen, C.P. Snow, Hortense Calisher, Robert Frost, Stephen Spender, W.H. Auden, Anais Nin and Wright Morris. Those who have been fellows make up a distinguished literary list. In poetry there has been Donald Hall, Philip Levine, Thom Gunn, Robert Pinsky and Robert Haas, while in fiction, Tillie Olsen, Dan Jacobson, Larry McMurty, Robert Stone, Stephen Dixon, Thomas McGuane and Raymond Carver (Rood 100-1).

Other American universities, fuelled by federal money, established writing programs after World War II and growth continued rapidly in succeeding decades with as many as a dozen new programs being set up each year in the 70s. A 1999 count of the The AWP Guide to Writing Programs found that 137 schools offered the MA in writing and 49 offered a Master of Fine Arts degree (Kulka and Danford 11). I will deal with some aspects of this proliferation and its impact on American literature in a later part of this paper.

\section{What Do Creative Writing Programs Offer?}

Writing in the mid-60s, Leslie Fiedler noted that the common plight of poets was an inability to subsist on poetry alone, a fact of life that had sent more poets into the classroom than into the world of competition and economic risk. Stegner agrees with this observation: there is truth, he says, in Samuel Butler's comment that "poverty and poetry are twin-born brats. In America, poetry is not a career; it is only the best part of one" (Rood 101). But there was more to it than this. Refuge in the college, argues Fiedler, drew the poet

...close to his own future, to the posterity for whom he writes. Certainly there he can, if he likes, tout himself and his friends, as well as abuse his rivals and his detractors; and there he can set the captive youngsters before him the task of understanding and loving...certain poems, including his own... Sometimes he fears, in fact, that the only reading such poems will get in the world he inhabits is precisely this vicarious or symbolic one, between college walls and class bells. (Fiedler 180)

Academe's embrace of the writer, if that is what we can call it, was not always so comfortable. Kazin says that when he was at university in the thirties, scholars were one class and writers another and there was an understanding that each should work in separate places. Knowledge was viewed historically, there were works that formed part of tradition, and scholars, within the university, were the custodians. "It was not always possible to say where this tradition began, but so far as literature was concerned, it ended at the cemetery. In 1938," Kazin writes, "a classmate of mine wanted to do his doctor's thesis on Dreiser, but was told flatly that he would not get permission until Dreiser was dead" (Kazin 244-5). It was only when this tradition, inherently cautious and conservative, broke down, that writers gained entrée into universities. 
So what have writers brought to this embrace? And what have students learnt from the experience of nurturing? A Wallace Stegner would say, in glowing terms, that he and his fellow teachers have seen some of the cream of American literary talent pass through Stanford. He mentions that he read the novels of a recent year as a juror for the National Book Awards and found that 20, better than ten percent, were by people he had known in a Stanford class (Rood 100). Not a bad success rate when measured by the yardstick of literary prizes and awards.

But I thought it might be useful to look at several specific experiences of the teacher/student or master/apprentice relationship. I have chosen two modern contemporary writers: Carver and Berryman.

\section{Carver}

In 1958, burning with the ambition to write yet conscious of the fact, as he said, that "I didn't know anything but I knew I didn't know anything," Raymond Carver enrolled at Chico State College (Carver 40). Among the classes he signed up for was Creative Writing 101. John Gardner was his teacher, someone already surrounded "by a bit of mystery and romance." Gardner, who had already written novels and short stories, was a real writer, and Carver, who had never laid eyes on a writer, "was in awe" (Carver 41). It turned out that Gardner, despite the mystique, was then still unpublished and his manuscripts were in boxes beside his desk. Aware of Carver's cramped family quarters, his teacher generously allowed him to work at weekends in Gardner's own office. There, Carver began his "first serious attempts at writing" (Carver 41).

Of the class instruction itself, Carver has said:

For short story writers in his class, the requirement was one story, ten to fifteen pages in length. For people who wanted to write a novel...a chapter of around twenty pages, along with an outline of the rest. The kicker was that this one short story, or the chapter of the novel, might have to be revised ten times in the course of the semester for Gardner to be satisfied with it. It was a basic tenet of his that a writer found what he wanted to say in the ongoing process of seeing what he'd said. And this seeing, or seeing more clearly, came about through revision... (Carver 42-3)

During classes, Gardner exposed his students to a variety of writers whose names, says Carver, he was not familiar with or whom he'd never read, including Conrad, Céline, Katharine Ann Porter, Isaac Babel, Chekov, Hortense Calisher and Robert Penn Warren.

Of Gardner's teaching, especially the one-on-one attention he gave to his students, Carver has observed that "he took my stories more seriously, read them closer and more carefully, than I had any right to expect" (Carver 44). Before their meeting, Gardner would have marked up Carver's story, giving it a close reading that was divided into deletions that were not negotiable and bracketed sentences, phrases, and words that were. The reasons behind the criticisms would be given. After that, they would tackle the larger concerns of the story, the "problem" it was trying to cast light on, the conflict it was trying to grapple with, and how the story fitted into the grand scheme of story writing. He taught Carver to avoid insensitvity, carelessness, sentimentality, and, above all, dishonesty (Carver 45).

Carver has said that he always retained from that short but important time (he was there for less than a year) the values and craft that Gardner instilled in him. Carver would have other mentors: his learning years as a writer included stints at the Iowa Writers' Workshop, Sacramento State College and a Stegner Fellowship at Stanford. But his 
unreserved praise he gives to Gardner. "I consider myself," wrote Carver, "the luckiest of men to have had his criticism and his generous encouragement" (47).

What of Carver the teacher? He taught creative writing at the University of California in Santa Cruz and Berkeley and later was Professor of English at Syracuse University from 1980-83. Jay McInerney who was Carver's student at Syracuse has commented that Carver's subject matter in his stories made his work depressing for some commentators but for many young writers "it was truly liberating" because his writing came to their attention when "academic metafiction was the regnant mode. His example reinvigorated realism as well as the short-story form" (McInerney 432).

McInerney says that Carver had a "light touch" as a teacher of creative writing and he did not consider it was his job to discourage anyone but he was capable of rigorous criticism and fortunate students had their stories subjected to the same process he employed in his own stories. A story might come back with Carver's deletions, substitutions, question marks and queries. There would be an extended discussion with the student who might rewrite the story many times. There are parallels here with Gardner's tutoring of Carver. McInerney recalls:

I took one story back to him seven times; he must have spent 15 or 20 hours on it. He was a meticulous, obsessive line editor. One on one, in his office, he almost became a tough guy, his voice gradually swelling with conviction. (McInerney 434)

Carver himself has commented that one of the dangers of teaching creative writing lies in the "overencouragement of young writers. But I learned from Gardner to take that risk rather than err on the other side" (Carver 46).

\section{Berryman}

John Berryman was, in his relatively short career, both a teacher of English literature as well as of creative writing. In 1954 he taught a poetry workshop at the University of Iowa which has become renowned. His student class included a number of writers who would go on to win international reputations: W.D. Snodgrass, Donald Justice, Philip Levine, Jane Cooper and William Dickey. Among this group, Berryman sought to instill "a sense of the importance and nobility of writing." Looking back on that time Levine has said that the workshop and the night class in poetry

'...were the best classes I've ever been part of...we loved him; it was the middle of the shittiest part of American life, the Rosenbergs had just been murdered, Joe McCathy was king, and John could make the study of poetry, our god damned mediocre poetry, the center of the world.' (cited in Haffenden 238)

In his classes Berryman was always spontaneous with applause and dislike for exercises his students submitted. One student recalled that

...there was even more to learn from him outside of class... as he talked almost exclusively about writing and writers and always in his tense, nervous, paranoid bombastic manner... In private, he was marvelously compassionate about his students and their work even though in class he was often devastatingly sarcastic, nasty and generally tough. But all of this was tempered by his brilliant wit and candid openness. (Haffenden 239)

What Berryman inspired in his students was his "total commitment to writing." One student says that "'He taught me, not only through his words but certainly his behaviour 
too, that creative awareness affords no compromises, no mercy; if authentic, perilous."' (cited in Haffenden 241).

\section{Dissenting Voices}

The comments that I've cited above are generally positive about the learning process a writer undergoes in creative writing programs. John Irving, who can probably be numbered among the sceptics of such programs, has remarked that as a student at Iowa he was not necessarily "taught" anything but he was "certainly encouraged and helped." His teachers, who included Vance Bourjaily, Kurt Vonnegut and José Donoso told him things about his writing and writing in general that he believes he would probably have eventually figured out for himself but what they did was save him "valuable time" and "time is precious for a young writer." Irving explains that he is referring to technical things, which is all he thinks "you can presume to teach, anyway" (Hansen 432).

E.L. Doctorow is more critical. The great danger, he argues, of having writing programs all over the country now is that "you are creating and training not just writers but teachers of writing" (Plimpton 318). A graduate gets an MFA in writing and moves to another campus to teach other young people to get their MFAs in writing. "Teachers of writing begetting teachers of writing" was bad. Young people, it was true, were more technically assured in their craft but

the horizon of the university-trained writers is diminished; the field for their work and attention is generally the bedroom, the living room, the family. The doors are closed, the shades are pulled down, and it's as if there were no streets outside, and no town, no highway, no society. (Plimpton 318)

Ted Solotaroff agrees. With the proliferation of graduate writing programs

the talent and seriousness of the students and their ability to teach each other becomes spread very thin... Even in a workshop in a topranked program today there will likely be among the fifteen students only a few who have the talent for a literary career, only one or two who have the determination; so it is hard to avoid a congenial tolerance of the ordinary, that is to say unnecessary, poem: what Donald Hall calls 'the MacPoem.' So, too, with fiction writing. (Solotaroff 252)

Mark Helprin acerbically comments that nothing is wrong with writing programs "except their central premise. It is simply not possible to teach someone to write...why not just give out vouchers for a good hotel in Venice?" The drive to write "must come from within, and the territory of operations must be uncharted: there is no teaching this" (Helprin xx).

He adds that while writing schools are "largely innocent of harmful effect, they may be part of the reason for the malignant presence of schools of writing." The collective impulse, he declares, does not sit well with writers. He illustrates his thesis with an attack on the school of minimalists:

What they do is as bad as what they believe in. They appear to start from the premise that the world has unjustly offended their innate virtue and forced them to become trenchant impassive observers of its universal offensiveness... Though minimalist 'classics' usually are fairly brief...they lend themselves to the short form not because they are poignant but because they are anaerobic... 
The dialect of the minimalists is their affectation of inscrutability and exhaustion. It is also their mask. Mice who tour lion country need masks and other tricks to have a safe trip. Besides, their unwillingness to deal with life other than obliquely is not subtlety, as they would have you think, but cowardice.

...they observe everything of great moment as if from a distance, as if it were in miniature, or under glass, as if when you pricked them, they would not bleed. (Helprin $\mathrm{xx}$-xxii)

But while Helprin picks apart the minimalist school, he doesn't actually name any single writer. In contrast, John Barth declares that minimalism underlies the most impressive phenomenon of the North American literary scene in the mid-80s - "the new flowering of the...short story," especially the "terse, oblique, realistic or hyperrealistic, slightly plotted, extrospective, cool-surfaced fiction" associated with "such excellent writers as Frederick Barthelme, Ann Beattie, Raymond Carver, Bobbie Ann Mason, James Robison, Mary Robison and Tobias Wolff" (Barth 65).

Barth traces the minimalist trajectory from Hemingway to Borges, Beckett and Carver. After running through some factors that explain the grip on American letters of the minimalist writers, he laments what he sees as the decline in reading and writing skills not only among the young (including young apprentice writers) but also among their teachers, many of whom are products of an "ever-less-demanding educational system and a society whose narrative-dramatic entertainment and tastes come far more from movies and television than from literature" (Barth 70). Among those aspiring writers promising enough to be admitted into good graduate writing programs, the general decline in basic language skills in the past two decades has been such that Barth worries "in some instances about their teaching undergraduates." In their writing, he finds it rare to locate a sentence of any syntactical complexity and "Dick-and-Jane prose tends to be emotionally and intellectually poorer than Henry James prose." For the great minimalist writers, "this impoverishment is elected and strategic" but for the less great "it may be faute de mieux" (71).

Barth observes, however, that "the minimalist authors of The New American Short Story are reenacting a cyclical correction in the history... of literature and of art in general." We can expect a change in which "the seven fat years are succeeded by seven lean, after which we...may look forward to the recorrection" (Barth 74).

Barth is far from being on the side of the Helprins and Doctorows. He doesn't want to close down the creative writing programs. He accepts that only a fraction of those who are admitted will end up becoming "successful writers" (by which he means individuals whose writings are frequently published) (Barth 27). This, he declares, is just as well, otherwise the country would be awash in writers. If one important writer emerges every several years from an annual seminar of ten or a dozen students that would be "an impressive score" provided that the odds are understood; that it is also understood that exceptional talent tends to cut through the odds; and that "all hands are learning something useful about the ancient medium and craft of literature..." (28).

Several of the critics of creative writing programs are saying that American fiction has become caught in a circular trap. The aspiring writer has become too cloistered and needs to get outside the academy, live life, and experience the world. Solotaroff even complains that the campus, by offering the writer the chance to teach, has changed the practice of the writing vocation in America. It has, he argues, "been responsible in good part for the vanishing of the man of letters as of the freelance intellectual" (Solotaroff 244). In addition, the training of writers within the university has meant that young writers of today are "afraid to attack the older ones because some of them have been their teachers" (249). 
Solotaroff offers a prescription. An antidote, as it were, to this perceived malaise of the creative writing process in the US. Universities should professionalise their writing programs by developing the training and values that would "inculcate a commitment to the profession of letters" (251). He proposes that:

- The program not admit writers until they are at least 25 years old (except in rare situations). The older student, probably having developed another skill besides writing, will bring with him or her different experiences, a more settled character, and maturity.

- Applicants should know well the work of at least 25 writers, distributed through literary history and several genres.

- Training should not be specialised but be devoted to the basics in different genres. A student would select an experience with a strong personal significance and express it as an essay, a story, a novella, a poem, a film script, a one-act play using the basic techniques and resources of each genre.

- Team teaching by rotation would be the practice: a poet and a playwright might teach the poetry segment. Such an approach would bring the faculty together to develop a pedagogy of teaching writing. - The program in creative writing would have links to the English and comparative literature departments so that cross-fertilisation would be encouraged.

- Training would be provided in travel writing, children's book writing and editing so that graduates had a better chance to survive by their pens rather than have no alternative but to teach or do something unrelated to writing. (Solotaroff 251-5)

Solotaroff is making a pitch for writing programs that broaden the skills of students and forge significant links with departments of English and comparative literature as a counterweight to the separation and specialisation that has become characteristic of many creative writing courses in American universities. His hope is for the kind of broadening in the emerging writer which turns him or her into a person of letters, someone who can write well in three or four modes, according to the subject (Solotaroff 73).

\section{References}

Barth, John. Further Fridays: Essays, Lectures, and Other Nonfiction 1984-94. New York: Little, Brown, 1995. Return to article.

Carver, Raymond. Fires: Essays, Poems, Stories. New York: Vintage Contemporaries, 1989. Return to article.

Ferguson, Paul F, John R. Maier, Frank McConnell, and Sara Mathiessen (interviewers). "John Gardner". Writers At Work. The Paris Review Interviews. Sixth Series. George Plimpton (ed). New York: Penguin, 1985. Return to article.

Fiedler, Leslie. Waiting For The End: The American Literary Scene from Hemingway to Baldwin. London: Jonathan Cape, 1965. Return to article.

Haffenden, John. The Life of John Berryman. London: Ark Paperbacks, 1983. Return to article. 
Hansen, Ron (interviewer). "John Irving". Writers At Work. The Paris Review Interviews. Eighth Series. George Plimpton (ed). New York: Penguin, 1988. Return to article.

Helprin, Mark. "Introduction". The Best American Short Stories 1988. Selected by Mark Helprin with Shannon Ravenel. Boston: Houghton Mifflin, 1988. Return to article.

Kazin, Alfred. The Inmost Leaf: A Selection of Essays. New York: Harcourt Brace Jovanovich, 1979. Return to article.

Kulka, John and Natalie Danford. "Preface". Scribner's Best of the Fiction Workshops 1999. Sherman Alexie (ed). New York: Scribner Paperback Fiction, 1999. Return to article.

McInerney, Jay. "Jay McInerney on Raymond Carver, August 6, 1989". The New York Times. Books of the Century: A Hundred Years of Authors, Ideas and Literature. Edited by Charles McGrath and the Staff of the Book Review. New York: Times Books, 1998. Return to article.

Malamud, Bernard. "Long Work, Short Life". Writers And Their Craft: Short Stories and Essays on the Narrative. Nicholas Delbanco and Laurence Goldstein (eds). Detroit: Wayne State University Press, 1991. Return to article.

Phillips, Robert (interviewer). "William Goyen". Writers At Work. The Paris Review Interviews. Sixth Series. George Plimpton (ed). New York: Penguin, 1985. Return to article.

Plimpton, George (interviewer). "E.L. Doctorow". Writers At Work. The Paris Review Interviews. Eighth Series. George Plimpton (ed). New York: Penguin, 1988. Return to article.

Rood, Karen L. "Schooldays". American Literary Almanac: From 1608 To The Present. Karen L Rood (ed). New York: Bruccoli Clark Layman, 1988. Return to article.

Solotaroff, Ted. A Few Good Voices in My Head: Occasional Pieces on Writing, Editing, and Reading My Contemporaries. New York: Harper and Rowe, 1987. Return to article.

Spires, Elizabeth (interviewer). "Elizabeth Bishop". Writers At Work. The Paris Review Interviews. Sixth Series. George Plimpton (ed). New York: Penguin, 1985. Return to article.

Stern, Daniel (interviewer). "Bernard Malamud". Writers At Work. The Paris Review Interviews. Sixth Series. George Plimpton (ed). New York: Penguin, 1985. Return to article.

Ken Chan is working on a higher degree in creative writing in the School of Creative Communication and Cultural Studies, University of Canberra. He wishes to thank Dr Jen Webb, University of Canberra, for her encouragement and support in the writing of this paper. 


\section{TEXT}

Vol 6 No 1 April 2002

http://www.griffith.edu.au/school/art/text/

Editors: Nigel Krauth \& Tess Brady

Text@mailbox.gu.edu.au 